\author{
В. А. Глива ${ }^{1}$, І. В. Матвєєва ${ }^{2}$, Л. А. Зозуля ${ }^{2}$, С. В. Зозуля ${ }^{2}$ \\ ${ }^{1}$ Київський національний університет будівництва і архітектури, Київ, Україна \\ ${ }^{2}$ Національний авіаційний університет, Київ, Україна
}

\title{
ДОСЛІДЖЕННЯ ЗАХИСНИХ ВЛАСТИВОСТЕЙ ЗАЛІЗОВМІСНОГО КОМПО- ЗИТУ ДЛЯ ЕКРАНУВАННЯ РЕНТГЕНІВСЬКИХ ВИПРОМІНЮВАНЬ
}

\begin{abstract}
Анотація. У роботі експериментально досліджено ефективність екранування рентгенівських випромінювань композиційними металовмісними матеріалами з наповнювачем із заліза. Показано, що для «м'якого» випромінювання коефіцієнти екранування складають 7 - 8. Перемішування рідкої металополімерної суміші ультразвуковим випромінюванням частотою 23 кГц 3 амплітудами $40-45$ мкм значно підвищує ефективність екранування (у $2-2,5$ рази). Розраховані масові коефіцієнти ослаблення рентгенівського випромінювання свідчать, що для енергій випромінювання 8-12 кеВ залізовмісний матеріал має кращі захисні властивості, ніж матеріал із вмістом свинцю. Дано розрахунок для врахування фактичної густини матеріалу для визначення масового коефіцієнта ослаблення. При цьому зарядовий номер елемента, який забезпечує розсіювання рентгенівського випромінювання залишається незмінним. Показано, що цей показник слід перераховувати для визначення внеску інших, ніж фотоефект, механізмів розсіювання іонізуючого випромінювання (утворення електрон-позитронних пар, ефект Комптона). Для підвищення ефективності композиційних рентгенозахисних матеріалів доцільно підвищити дисперсність та ваговий вмістзалізного концентрату у полімерній матриці. За співвідношення заліза та полімеру 3:1 (за вагою) матеріал втрачає гнучкість i може застосовуватись у вигляді облицювальних плиток. Для підвищення коефіцієнтів екранування «жорсткого» випромінювання у матеріал доцільно додавати сполуки вольфраму у невеликій кількості. Перспективним напрямом досліджень щодо застосування безсвинцевих матеріалів $\epsilon$ підвищення дисперсності наповнювачів з елементів 3 меншими зарядовими числами.
\end{abstract}

Ключ ов і сл ов а: іонізуюче випромінювання, композиційний матеріал, екранування, ультразвук.

\section{Вступ}

Захист населення та працюючих від впливу іонізуючого випромінювання залишається в Україні актуальною проблемою. Значною мірою це стосується рентгенівського випромінювання різної ж орсткості через застосування цих випромінювань як робочих у промисловості та охороні здоров'я. Так, на сьогоднішній день усі стоматологічні кабінети повинні бути обладнанні рентгенівськими апаратами. Такі кабінети розташовуються, здебільшого, у житлових будинках, тому застосування захисних конструкцій із вмістом свинцю та його сполук заборонено. Пошук шляхів створення матеріалів на заміну матеріалів із вмістом свинцю $є$ загальносвітовою тенденцією як через його токсичність, так і відносно високу вартість та складність монтажу захисних конструкцій. Одним із можливих замінників $€$ композиційний матеріал на основі полімеру й заліза та його сполук, що потребує проведення ретельних експериментальних та теоретичних досліджень.

Аналіз останніх публікацій і досліджень. Більшість досліджень у цій галузі стосуються матеріалів для захисту від гама-випромінювань, які заздалегідь ефективно екранують рентгенівські випромінювання $[1,2]$. У цих роботах розглядаються матеріали, у яких захисними елементами є диспрозій та гадоліній, а також сполуки елементів 3 малим зарядовим числом бора та лужних металів. Очевидно, що такі наповнювачі, навіть за високих ефективностей, роблять захисні матеріали дуже дорогими і непридатними для масового застосування. Навіть для рентгенозахисних матеріалів застосовують композиції на полімерній основі 3 вмістом вісмуту та вольфраму [3]. Те ж саме стосується матеріалу з вуглецевими наповнювачами [4]. За- звичай захист від випромінювань рентгенівської частини спектра частот (енергій) простіший, тому створення матеріалів великої вартості економічно не виправдане. Взагалі відмінності матеріалів, що досліджуються стосуються, в основному, матеріалів матриць композицій. У роботі [5] це етилен-вініл-ацетат 3 наповнювачем з вольфраму, у [6] - поліетилени зі сполуками барію, триоксидувісмути та оксиду вольфраму. Застосовується також епоксидна смола через відсутність деградації під впливом іонізуючих випромінювань [7]. У роботі [8] досліджено принципові можливості й визначені енергії, для яких композиційний залізовмісний матеріал буде достатньо ефективним. Зазвичай діагностичне обладнання не генерує рентгенівських випромінювань високих енергій, до того ж найбільшу небезпеку становлять побічні (паразитні) випромінювання малої інтенсивності, для яких великі коефіцієнти екранування не потрібні.

Мета роботи - дослідити коефіцієнти екранування рентгенівських випромінювань металополімерними композиціями на основі заліза та його сполук.

\section{Виклад основного матеріалу}

Для виготовлення зразків використовувався рідкий латекс та залізорудний концентрат (вміст заліза $60-68 \%$, середній розмір залізорудних частинок 22 - 23 мкм). Концентрат виготовлено на Полтавському ГЗК. Сухий залізорудний концентрат додавався до латексу у кількості 60 \% (за вагою). Суміш спочатку перемішувалася механічно упродовж 15 хв., а потім упродовж 10 хв. Оброблялася ультразвуком частотою 23 кГц амплітудою 40 - 45 мкм. Отримана суміш наливалася на пласкі поверхні шарами різної товщини. Після полімеризації зразки були готові до використання. Розміри зразків 0,2 × 0,2 м. Визначення 
ефективності захисту здійснювалося методом прямих вимірювань СРП-68-01. Вимірювався рівень рентгенівського випромінювання джерела перед і після захисного екрана. Джерелом рентгенівського випромінювання слугував медичний рентгенівський апарат Neo-Diagnomax 3 робочими напругами на рентгенівській трубці $40-125 \kappa \mathrm{V}$.

У процесі досліджень визначалися захисні властивості маталополімерних композицій без застосування ультразвукової обробки рідкої вихідної суміші і обробленої ультразвуком (рис. 1).

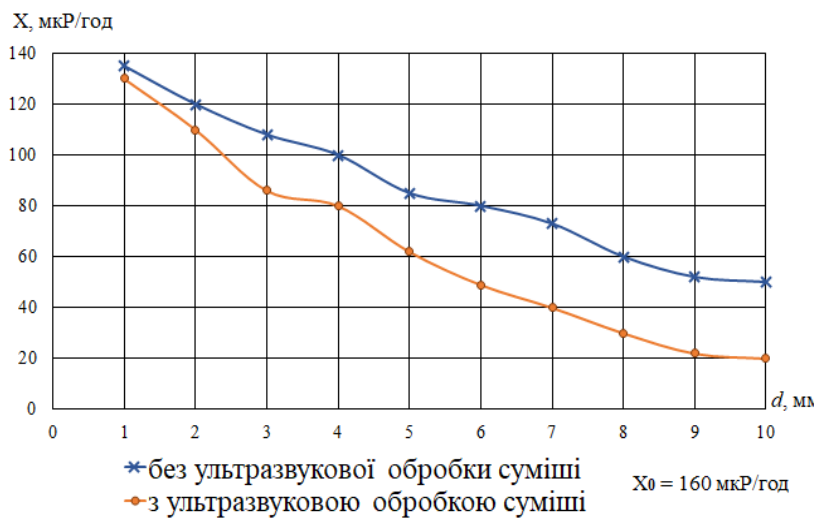

Рис. 1. Зниження інтенсивності рентгенівського випромінювання металополімером на основі залізовмісного порошку

Як видно з графіків, ультразвукове перемішування металополімерної суміші значно підвищує захисні властивості матеріалу. Очевидно, це пов'язано $з$ підвищенням дисперсності наповнювача, рівномірністю й щільністю розташування металевих частинок у тілі матриці, що підвищує імовірність взаємодії рентгенівського кванта $з$ речовиною. Але коефіцієнти екранування матеріалів відносно невеликі 7-8, хоча для більшості умов експлуатації рентгенівського обладнання цілком достатні. Такі ефективності можна пояснити тим, що під час проведення експериментів застосовувалося рентгенівське випромінювання енергією близько 50 кеВ, що згідно [8] відповідає найнижчій ефективності заліза порівняно зі свинцем. Доцільно розрахувати розподіл ефективності залізовмісних композицій, яка залежить від масового коефіцієнта ослаблення $\mu_{\mathrm{M}}=\mu / \rho$, де $\mu$-лінійний коефіцієнт ослаблення матеріалу; $\rho-$ густина матеріалу. Коефіцієнт ослаблення залежить від енергій рентгенівського випромінювання (рис. 2).

Аналіз результатів свідчить, що для енергій 8 12 кеВ залізовмісний матеріал має кращі функціональні показники, ніж матеріал на основі свинцю.

Для більшості медико-діагностичних застосувань відмінності енергій, наведених на рис. 2 несуттєві. У загальному випадку енергія рентгенівського випромінювання залежить від прискорюючої напруги у лампі та матеріалу, з якого виготовлений анод трубки. За певних умов можна вирішити питання достатності захисних властивостей залізовмісного композиту, що значно спростить формальні процедури застосування рентгенівської техніки.

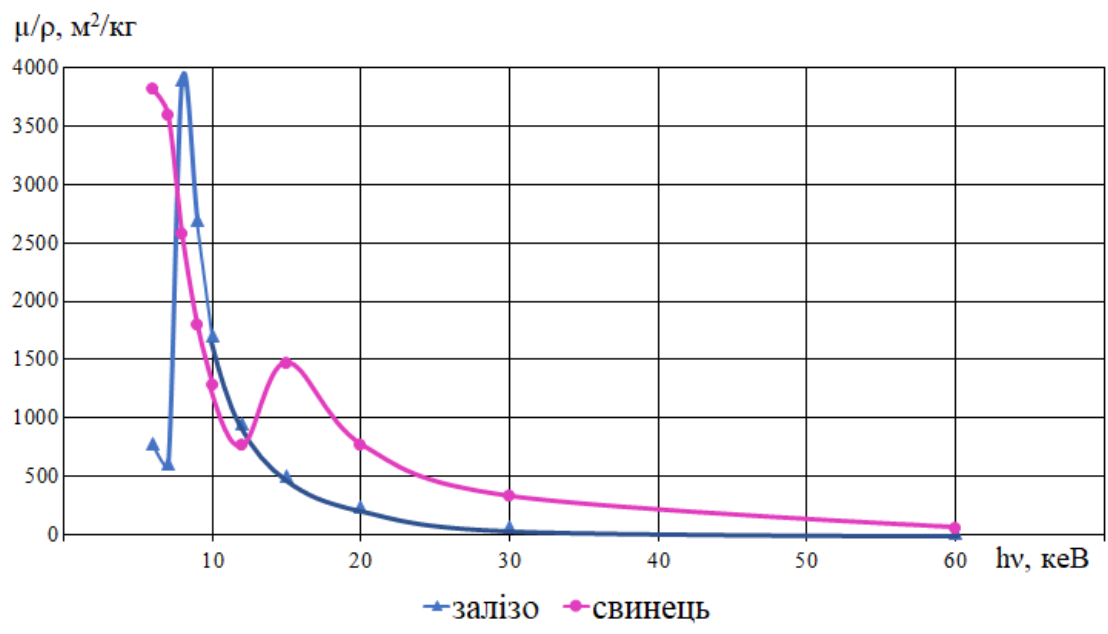

Рис. 2. Залежність захисних властивостей матеріалів від енергії рентгенівського випромінювання

Для малих енергій випромінювань превалюючим механізмом розсіювання рентгенівських квантів $\epsilon$ фотоефект. Масовий коефіцієнт ослаблення $\tau / \rho$ однозначно визначається як:

$$
\frac{\tau}{\rho}=\frac{\mathrm{Z}^{4}}{(\mathrm{~h} v)^{2}},
$$

де $\mathrm{Z}$ - порядковий номер елемента, який забезпечує захист; $\rho$ - його густина; $\mathrm{h}$ - стала Планка $\left(6,62 \cdot 10^{34}\right.$ Дж·c); $v$ - частота рентгенівського кванта.
У цьому співвідношенні $\mathrm{Z}$ порядковий номер металу у періодичній таблиці, саме він забезпечує захист, але $\rho$ матеріалу відрізняється від густини металу. Наприклад, у даному випадку (рис.1) кількість залізовмісної субстанції $60 \%$, тобто $\mathrm{m}_{\mathrm{M}}=1,5 \mathrm{~m}_{\Pi}$ (маса металу у 1,5 рази більша маси полімеру). Це треба враховувати для оціночного розрахунку захисних властивостей композицій.

Якщо $\mathrm{m}_{\mathrm{M}}=\mathrm{km}_{\text {п }}$, а $\rho=m / v$, то $\rho$ суміші визначається як: 


$$
\rho=\frac{\rho_{\mathrm{M}} \cdot \rho_{\Pi} \cdot(k+1)}{k \rho_{\Pi}+\rho_{\mathrm{M}}},
$$

де $\rho_{\mathrm{M}}$ та $\rho_{\text {п }}-$ густина металу й полімеру, застосованих для виготовлення композитного рентгенозахисного матеріалу.

Цей підхід слушний не тільки для використання співвідношення (1), а й для визначення внеску інших механізмів розсіювання іонізуючих випромінювань (утворення електрон-позитронних) пар, ефект Комптона).

Як зазначалося, ефективність дослідженого матеріалу не зовсім прийнятна для «жорсткого» рентгенівського випромінювання та гамма-випромінювань, поширених у медичній та технічних галузях.

Щодо використання залізорудного концентрату, то можливі кілька шляхів підвищення якості композитів на його основі.

Найпростіший - збільшення вагового внеску заліза у полімер. Попередні експерименти свідчать, що вагове співвідношення наповнювач-полімер може бути й 3:1. При цьому полімер є звичайним в'яжучим і виріб втрачає гнучкість, але у більшості випадків облицювання приміщень, що потребують захисту, здійснюється облицювальними плитками. Доцільно розглянути можливість додавання у вихідну суміш екрануючих елементів типу сполук вольфраму, але у менших кількостях порівняно з іншими виробами. Це дозволить не збільшувати товщину залізополімерних матеріалів, що у багатьох випадках є критичним.

\section{Висновки}

1. Дослідження довели, що застосування композиційного матеріалу із вмістом заліза у кількості $60 \%$ (за вагою) і більше ефективне для захисту від рентгенівських випромінювань з енергіями $8-12$ кеВ.

2. Коефіцієнт екранування залізополімерного матеріалу для фіксованої енергії випромінювання практично лінійно підвищується зі збільшенням товщини екрана.

3. Для попередніх оцінок ефективності композиційних матеріалів у співвідношеннях з їх розрахунків слід враховувати фактичну густину композиції за використання зарядового числа металевого наповнювача.

\title{
СПИСОК ЛІТЕРАТУРИ
}

1. Singh, V.P., Badiger, N. M. Kothan, S., Kaewjaeng, S., Korkut, T., Kim, H. J., Kaewkhao, J., 2015. Gamma- ray and neutron shielding efficiency of $\mathrm{Pb}$-free gadolinium based glasses. Journal of Nuclear Science and Techniques, 27(4), 103.

2. Mann, K. S., Rani, A., Heer, M. S., 2015. Shielding behaviors of some polymer and plastic materials for gamma-rays. Radiation Physics and Chemistry, 106, 247-254.

3. Рентгенозащитная композиция: пат. 2294030 Россия: МПК G21F 1/10 / Г.Г. Савкин, Р.В. Кушникова, Е.С. Назарова, Г,Ф. Пряникова и др. № 2002126334/06; заявл. 02.10.2002; опубл. 20.02.2007, Бюл. № 5.- 6 с.

4. Углеродсодержащая композиция: пат. 2519244 Россия: МПК H01G 17/00, G21F 1/00 / В.В. Поливкин, В.Н. Гульбин, В.А. Михеев, Н.С. Колпаков. № 2012145071/07; заявл. 24.10.2012; опубл. 10.06.2014, Бюл. № 16.- 6 с.

5. Ersoz, O. A., Lambrecht, F. Y., Soylu, H. M., 2016. Tungsten-ethylene vinyl acetate (EVA) composite as a gamma rays shielding material. Indian Journal of Pure \& Applied Physics, 54 (12), 793-796.

6. Seon-Chil Kim and Sung-Hyoun Cho., 2019. Analysis of the Correlation between Shielding Material Blending Characteristics and Porosity for Radiation Shielding Films. Journals Applied Sciences 9(9), 1765; https://doi.org/10.3390/app9091765.

7. Джур Е.А., Санин А.Ф., Божко С.А., Андрианов А.Ю., Белоус В.А., Рыбка А.В., Захарченко А.А., Борисенко В.Н., Зиновьев А.М., Кузнецов А.П., Плисак Ю.В., 2013. Композиционный материал для защиты радиоэлектронной аппаратуры космических аппаратов от ионизирующего излучения. Вестник Сибирского государственного аэрокосмического университета им. академика М.Ф. Решетнева. № 6 (52). С. 126-131.

8. Глива В.А. Проектування композитних матеріалів на основі дрібнодисперсної залізовмісної субстанції для екранування іонізуючих випромінювань / В.А. Глива, І.В. Матвєєва, Л.О. Левченко, Н.М. Кічата // Системи управління, навігації та зв’язку. - 2020. - № 2 (60). С. 110-113.

Received (Надійшла) 15.07.2021

Accepted for publication (Прийнята до друку) 25.08.2021

\section{The investigation of protective properties of iron-containing composite for X-ray shielding}

\author{
V. Glyva, I. Matvieieva, L. Zozulia, S. Zozulia
}

Abstract. The paper presents experimental investigation of the efficiency of X-ray shielding by composite metal-containing materials with iron filler. It demonstrates that for "soft" radiation the shielding coefficients are 7-8. Mixing the liquid metalpolymer mixture with ultrasonic radiation with a frequency of $23 \mathrm{kHz}$ with amplitudes of $40-45 \mu \mathrm{m}$ significantly increases the shielding efficiency (by 2-2.5 times). The calculated mass attenuation coefficients of X-ray radiation show that for radiation energies of 8-12 keV the iron-containing material has better protective properties than the material with lead content. It offers the calculation, which takes into account the actual density of the material to determine the mass attenuation coefficient. In this case, the charge number of the element that provides scattering of X-rays remains unchanged. It is shown that this indicator should be recalculated to determine the contribution of mechanisms other than the photoeffect of ionizing radiation scattering (formation of electron-positron pairs, Compton effect). To increase the efficiency of composite X-ray protective materials, it is advisable to increase the dispersion and weight content of iron concentrate in the polymer matrix. At a ratio of iron and polymer 3: 1 (by weight) the material loses flexibility and can be used in the form of facing tiles. To increase the shielding coefficients of "hard" radiation, it is advisable to add a small amount of tungsten compounds to the material. A promising area of research on the use of lead-free materials is the increased dispersion of fillers from elements with lower charge numbers.

Keyw ord s: ionizing radiation, composite material, shielding, ultrasound. 